\title{
Pengaruh motivasi berwirausaha, pembelajaran kewirausahaan, dan penggunaan media sosial terhadap minat berwirausaha pada mahasiswa prodi S1 pendidikan ekonomi angkatan 2017 Universitas Negeri Malang
}

\author{
Rosalia Vernanda, Lisa Rokhmani* \\ Universitas Negeri Malang, Jl. Semarang No. 5 Malang, Jawa Timur, Indonesia \\ *Penulis korespondensi, Surel: lisa.rokhmani.fe@um.ac.id
}

Paper received: 25-8-2021; revised: 8-9-2021; accepted: 15-9-2021

\begin{abstract}
This research was conducted to determine the partial or simultaneous influence of entrepreneurship motivation, entrepreneurship learning and the using of social media on entrepreneurship interest of Economics Education departement students class of 2017, State University of Malang. The research method in this research is quantitative with the type of explanatory research. The population in this study were undergraduate students of Economics Education class of 2017 State University of Malang, with a total sample of 100 students. The sampling technique used purposive sampling and primary data collection using a questionnaire. The analysis prerequisite tests in this study include normality, multicollinearity and heteroscedasticity. The data analysis technique in this study used multiple linear regression analysis techniques. The results of the study show (1) partially there is an effect of entrepreneurship motivation on entrepreneurship interest, (2) partially there is an influence of entrepreneurship learning on entrepreneurship interest, (3) partially there is an effect of using social media on entrepreneurship interest, and (4) simultaneously there is an influence of entrepreneurship motivation, entrepreneurship learning and the using of social media on entrepreneurship interest. The conclusion of this study is that there is an influence of entrepreneurship motivation, entrepreneurship learning and the using of social media on entrepreneurship interest of Economics Education departement student at Malang State University class of 2017.
\end{abstract}

Keywords: entrepreneurship motivation; entrepreneurship learning; using of social media; entrepreneurship interest

\begin{abstract}
Abstrak
Penelitian ini bertujuan untuk menentukan pengaruh parsial atau simultan dari motivasi kewirausahaan, pendidikan kewirausahaan dan penggunaan media sosial pada minat berwirausaha mahasiswa jurusan pendidikan ekonomi, Universitas Negeri Malang, tahun 2017. Penelitian ini merupakan penilitian kuantitatif dengan tipe penelitian eksplanatori. Sampel dari penelitian ini merupakan 100 mahasiswa jurusan pendidikan ekonomi, Universitas Negeri Malang, tahun 2017. Sampel dipilih menggunakan teknik purposive sampling dan data didapatkan melalui kuesioner. Tes statistic prasyarat pada penelitian ini meliputi tes normalitas, multikolinearitas, dan heteroskedastisitas. Teknik regresi linear berganda digunakan untuk proses analisa data. Hasil analisis menunjukkan bahwa (1) adanya efek partial dari motivasi kewirausahaan pada minat berwirausaha, (2) adanya efek partial dari pendidikan kewirausahaan pada minat berwirausaha (3) adanya efek partial dari penggunaan media sosial pada minat berwirausaha, dan (4) adanya efek simultan dari motivasi berwirausaha, pendidikan kewirausahaan, dan penggunaan media sosial pada minat berwirausaha. Sehingga, motivasi kewirausahaan, pendidikan kewirausahaan, dan penggunaan media sosial membawa pengaruh pada minat berwirausaha mahasiswa pendidikan ekonomi tahun 2017, Universitas Negeri Malang.
\end{abstract}

Kata kunci: motivasi kewirausahaan; pendidikan kewirausahaan; penggunaan media sosial; minat berwirausaha 


\section{Pendahuluan}

Jumlah pengangguran di Indonesia dari tahun ke tahun jumlahnya selalu berubah-ubah. Para pencari kerja baik yang telah memiliki gelar sarjana maupun yang tidak memiliki gelar harus dapat bersaing untuk mendapatkan lapangan pekerjaan dengan kondisi jumlah lapangan pekerjaan yang terbatas. Berdasarkan data yg diperoleh dari BPS jumlah angka pengangguran untuk lulusan perguruan tinggi pada tahun 2017 bulan Februari sebanyak 11,59 juta orang dan pada tahun 2018 bulan Februari mengalami peningkatan yaitu sebanyak 11,71 juta orang, alasan yang dinilai menjadi penyebab dari meningkatnya jumlah pengangguran pada lulusan perguruan tinggi diantaranya yaitu sebagian dari mereka enggan untuk berwirausaha. Sehingga solusi untuk mengurangi angka pengangguran pada lulusan perguruan tinggi ini yaitu salah satunya menjadi seorang wirausahawan. wirausaha dapat didefinisikan sebagai setiap orang yang memiliki kemampuan untuk menemukan dan melihat suatu peluang usaha serta dapat memanfaatkannya sebagai suatu tujuan dalam membuka bisnis atau usaha, hal ini sesuai dengan teori yang dikemukakan oleh (Alfianto, 2012).

Seorang wirausahawan akan diawali dari adanya minat berwirausaha yang dimiliki oleh dirinya. Besarnya minat yang dimiliki oleh individu sangat tergantung pada kuatnya hubungan yang dimiliki antara diri sendiri serta lingkungan sekitar, hal ini sesuai dengan pernyataan yang dikemukakan oleh (Kamal \& Thoyyibah, 2020). Faktor-faktor yang mempengaruhi minat berwirausaha diantaranya faktor yang berasal dari dalam diri seseorang maupun dari luar atau lingkungan sekitar, pernyataan ini sesuai dengan penelitian yang sebelumnya dilakukan oleh (Sari, dkk., 2018). Sehingga dalam hal ini minat seseorang tidak muncul begitu saja melainkan tumbuh dan berkembang sesuai dengan faktor-faktor yang mempengaruhinya. Misalnya saja terdapat beberapa faktor yang memberikan pengaruh terhadap minat individu untuk berwirausaha diantaranya yaitu adanya motivasi berwirausaha, pembelajaran kewirausahaan dan penggunaan media sosial.

Pada penelitian ini yang menjadi latar belakang untuk melaksanakan penelitian pada mahasiswa Prodi S1 Pendidikan Ekonomi angkatan 2017 karena kebanyakan dari mereka mulai tertarik dan berminat untuk berwirausaha bahkan beberapa sebagian dari mereka telah memiliki bisnis atau usaha baik itu usaha online maupun konvensional, serta berbagai jenis usaha yang dijalankannya mulai dari usaha kuliner, pakaian, kosmetik, dan lain-lain. Ketertarikan seorang mahasiswa dalam dunia usaha dapat dikarenakan adanya motivasi berwirausaha, adanya berbagai media sosial yang digunakan oleh mahasiswa maupun adanya kegiatan pembelajaran kewirausahaan yang pernah diikutinya pada semester 6 lalu. Motivasi itu sendiri dapat diartikan sebagai kekuatan atau dorongan yang dimiliki oleh individu untuk melakukan suatu tindakan tertentu dalam mencapai tujuan tertentu, penjelasan ini sesuai dengan teori yang dikemukakan oleh (Aradea, 2018). Sedangkan motivasi berwirausaha itu sendiri dapat dipengaruhi oleh faktor dari dalam diri atau intrinsik maupun dari lingkungan sekitar atau ekstrinsik, penjelasan ini sesuai dengan yang dikemukakan oleh (Iswandari, 2013) dalam penelitiannya yang pernah dilakukan. Selain motivasi terdapat pembelajaran kewirausahaan yang dapat mempengaruhi minat berwirausaha pada mahasiswa. Pembelajaran kewirausahaan itu sendiri menurut (Suyatno \& Muhtarom, 2018) adalah pendidikan yang mengajarkan agar orang mampu menciptakan kegiatan usaha sendiri. Sehingga dapat diartikan bahwa pembelajaran kewirausahaan merupakan suatu kegiatan yang sifatnya mendidik untuk mengajak orang atau sekelompok orang agar nantinya mereka memperoleh sebuah pengetahuan tentang bagaimana seseorang itu nantinya dapat atau mampu membuka maupun mendirikan usaha sendiri. Melalui kegiatan pembelajaran 
kewirausahaan ini dapat membentuk jiwa wirausaha pada mahasiswa. Kemudian yang terakhir salah satu faktor yang juga dapat mempengaruhi minat berwirausaha pada mahasiswa yaitu adanya penggunaan media sosial. Kegiatan perekonomian suatu negara khususnya Indonesia sebagian besar telah banyak ditopang oleh internet, termasuk salah satu diantaranya adalah dalam bidang kewirausahaan. Pada saat ini semakin banyak masyarakat khususnya kalangan anak mudah yang aktif menggunakan media sosial. Dengan menggunakan media sosial tersebut maka seorang individu dapat dengan mudah mencari berbagai informasi-informasi terkait peluang usaha maupun berbagai ide - ide menarik dalam berbisnis. Selain itu dengan adanya media sosial ini masyarakat dapat dengan mudah melakukan kegiatan promosi dengan lebih hemat. Dengan adanya berbagai kemudahan yang dimiliki dalam menggunakan media sosial ini dapat menumbuhkan minat berwirausaha khususnya di kalangan mahasiswa, hal ini sesuai dengan penelitian yang sebelum dilakukan oleh (Sahroh, 2018) yang menyatakan bahwa penggunaan media sosial berpengaruh terhadap minat berwirausaha pada mahasiswa.

Perbedaan penelitian ini dengan penelitian-penelitian sebelumnya yaitu pada penelitian ini membahas pengaruh secara bersama-sama antara variabel motivasi berwirausaha, pembelajaran kewirausahaan dan penggunaan media sosial terhadap minat berwirausaha pada mahasiswa. Sedangkan pada penelitian-penelitian sebelumnya masih belum ada yang membahas mengenai pengaruh motivasi berwirausaha, pembelajaran kewirausahaan dan penggunaan media sosial yang secara bersama-sama dapat mempengaruhi minat berwirausaha pada mahasiswa. Seperti penelitian yang dilakukan oleh Wijayangka, dkk. (2018) yang dalam penelitiannya hanya membahas mengenai pengaruh motivasi terhadap minat berwirausaha. Selain itu juga terdapat penelitian dari Amanda (2018) yang pada penelitiannya hanya membahas mengenai pengaruh pembelajaran kewirausahaan, lingkungan pergaulan dan latar belakang ekonomi keluarga terhadap minat berwirausaha. Kemudian terdapat juga penelitian dari (Sahroh, 2018) yang pada penelitiannya hanya melihat pengaruh literasi ekonomi dan tingkat penggunaan media sosial terhadap minat berwirausaha.

Berdasarkan penjelasan di atas, baik itu motivasi berwirausaha, pembelajaran kewirausahaan dan penggunaan media sosial yang diperkirakan dapat memberikan pengaruh terhadap minat berwirausaha khususnya pada mahasiswa S1 Pendidikan Ekonomi angkatan 2017. Oleh karena itu, tujuan dari penelitian ini yaitu diantaranya: (1) untuk mengetahui pengaruh motivasi berwirausaha terhadap minat berwirausaha pada mahasiswa S1 Pendidikan Ekonomi angkatan 2017, (2) Untuk mengetahui pengaruh pembelajaran kewirausahaan terhadap minat berwirausaha pada mahasiswa S1 Pendidikan Ekonomi angkatan 2017, (3) Untuk mengetahui pengaruh penggunaan media sosial terhadap minat berwirausaha mahasiswa S1 Pendidikan Ekonomi angkatan 2017, dan (4) Untuk mengetahui pengaruh motivasi berwirausaha, pembelajaran kewirausahaan dan penggunaan media sosial terhadap minat berwirausaha pada mahasiswa S1 Pendidikan Ekonomi angkatan 2017.

\section{Metode}

Penelitian ini menggunakan metode penelitian kuantitatif dengan jenis penelitian eksplanasi. Penggunaan metode kuantitatif dengan jenis penelitian eksplanasi dilakukan dengan tujuan untuk mengetahui seberapa besar pengaruh antara variabel bebas yang berupa motivasi berwirausaha (X1), pembelajaran kewirausahaan (X2), dan penggunaan media sosial (X3) terhadap variabel terikat yaitu minat berwirausaha (Y). Populasi dalam penelitian ini yaitu mahasiswa S1 Pendidikan Ekonomi angkatan 2017 yang terdiri atas lima offering dengan 
jumlah 133 mahasiswa. Penentuan sampel dalam penelitian ini akan berdasarkan pada karakteristik tertentu yaitu pada mahasiswa angkatan 2017 prodi S1 Pendidikan Ekonomi Fakultas Ekonomi dan Bisnis Universitas Negeri Malang yang telah menempuh mata kuliah kewirausahaan, dalam hal ini berjumlah 100 mahasiswa. Teknik pengambilan sampel dalam penelitian ini menggunakan teknik purposive sampling. Instrument penelitian yang digunakan yaitu angket dan dokumentasi. Penyebaran angket digunakan untuk mengukur pengaruh variabel-variabel bebas yang terdiri atas motivasi berwirausaha, pembelajaran kewirausahaan, dan penggunaan media sosial terhadap variabel terikat yaitu minat mahasiswa untuk berwirausaha. Angket ini disebarkan secara online melalui WhatsApp kepada masingmasing responden. Sedangkan dokumentasi digunakan untuk memperoleh data dari dokumen-dokumen yang dimiliki oleh Universitas Negeri Malang maupun dari jurnal-jurnal ilmiah yang dapat mendukung kegiatan penelitian. Teknik dokumentasi ini dilakukan salah satunya untuk mendapatkan data tentang jumlah mahasiswa prodi S1 Pendidikan Ekonomi angkatan 2017 maupun data-data lain yang dapat digunakan sebagai kajian dalam penelitian.

Instrument yang digunakan dalam penelitian ini sebelumnya telah melakukan pengujian instrumen kepada 30 responden dengan hasil secara keseluruhan bahwa instrument yang digunakan telah dinyatakan valid dan reliabel. Langkah-langkah analisis data yang digunakan pada penelitian ini yaitu diantaranya analisis statistik deskriptif, uji normalitas, uji multikolinearitas, uji heteroskedastisitas, analisis regresi linear berganda, uji hipotesis, uji koefisien determinasi dan sumbangan efektif.

\section{Hasil dan Pembahasan}

\subsection{Hasil}

\subsubsection{Analisis Statistik Deskriptif}

\subsubsection{Motivasi Berwirausaha (X1)}

Nilai Minimum : 18

Nilai Maximum : 40

Mean : 33,58

Simpangan Baku / Standard Deviasi : 4,719

Tabel 1. Distribusi Frekuensi Motivasi Berwirausaha $\left(\mathrm{X}_{1}\right)$

\begin{tabular}{lllll}
\hline No. & \multicolumn{1}{c}{$\begin{array}{c}\text { Kelas } \\
\text { Interval }\end{array}$} & \multicolumn{1}{c}{ Kategori } & Frekuensi & Persentase \\
\hline 1 & $36-42$ & Sangat Tinggi & 37 & $37 \%$ \\
2 & $29-35$ & Tinggi & 52 & $52 \%$ \\
3 & $22-28$ & Sedang & 8 & $8 \%$ \\
4 & $15-21$ & Rendah & 3 & $3 \%$ \\
5 & $8-14$ & Sangat & 0 & $0 \%$ \\
Total & & Rendah & 100 & $100 \%$ \\
\hline
\end{tabular}

Berdasarkan tabel 1 dapat diketahui bahwa mahasiswa prodi S1 Pendidikan Ekonomi Angkatan 2017 memiliki motivasi berwirausaha dengan kategori sangat tinggi sebanyak 37 mahasiswa dengan persentase sebesar $37 \%$. Selain itu, sebanyak 52 mahasiswa masuk dalam 
kategori tinggi dengan persentase sebesar 52\%. Untuk kategori sedang terdapat 8 mahasiswa dengan persentase sebesar $8 \%$. Kemudian untuk kategori rendah terdapat 3 mahasiswa dengan persentase sebesar 3\%. Sedangkan untuk kategori sangat rendah tidak terdapat mahasiswa yang termasuk pada kategori tersebut. Hal ini dapat dibuktikan dari nilai distribusi frekuensi yang menunjukkan bahwa nilai frekuensi untuk variabel motivasi berwirausaha yaitu 0 dengan persentase $0 \%$. Sehingga, dari data distribusi frekuensi tersebut maka dapat disimpulkan bahwa sebagian besar mahasiswa prodi S1 Pendidikan Ekonomi Angkatan 2017 Universitas Negeri Malang memiliki motivasi berwirausaha yang tergolong tinggi.

\subsubsection{Pembelajaran Kewirausahaan (X2)}

Nilai Minimum : 21

Nilai Maximum : 40

Mean : 31,62

Simpangan Baku / Standard Deviasi : 3,247

Tabel 2. Distribusi Frekuensi Pembelajaran Kewirausahaan $\left(\mathrm{X}_{2}\right)$

\begin{tabular}{lllll}
\hline No. & Kelas Interval & \multicolumn{1}{c}{ Kategori } & \multicolumn{1}{c}{ Frekuensi } & Persentase \\
\hline 1 & $36-42$ & Sangat Tinggi & 11 & $11 \%$ \\
2 & $29-35$ & Tinggi & 81 & $81 \%$ \\
3 & $22-28$ & Sedang & 7 & $7 \%$ \\
4 & $15-21$ & Rendah & 1 & $1 \%$ \\
5 & $8-14$ & Sangat Rendah & 0 & $0 \%$ \\
Total & & & 100 & $100 \%$ \\
\hline
\end{tabular}

Berdasarkan tabel 2 dapat diketahui bahwa mahasiswa prodi S1 Pendidikan Ekonomi Angkatan 2017 memiliki pembelajaran kewirausahaan dengan kategori sangat tinggi sebanyak 11 mahasiswa dengan persentase sebesar 11\%. Selain itu, sebanyak 81 mahasiswa masuk dalam kategori tinggi dengan persentase sebesar $81 \%$. Untuk kategori sedang terdapat 7 mahasiswa dengan persentase sebesar 7\%. Kemudian untuk kategori rendah terdapat 1 mahasiswa dengan persentase sebesar 1\%. Sedangkan untuk kategori sangat rendah tidak terdapat mahasiswa yang termasuk pada kategori tersebut. Hal ini dapat dibuktikan dari nilai distribusi frekuensi yang menunjukkan bahwa nilai frekuensi untuk variabel pembelajaran kewirausahaan yaitu 0 dengan persentase $0 \%$. Sehingga, dari data distribusi frekuensi tersebut maka dapat disimpulkan bahwa sebagian besar mahasiswa prodi S1 Pendidikan Ekonomi Angkatan 2017 Universitas Negeri Malang memiliki tingkat pembelajaran kewirausahaan yang tergolong tinggi. 


\subsubsection{Penggunaan Media Sosial (X3)}

Nilai Minimum : 18

Nilai Maximum : 30

Mean : 26,73

Simpangan Baku / Standard Deviasi : 2,874

Tabel 3. Distribusi Frekuensi Penggunaan Media Sosial $\left(\mathrm{X}_{3}\right)$

\begin{tabular}{lllll}
\hline No. & Kelas Interval & Kategori & Frekuensi & Persentase \\
\hline 1 & $26-30$ & Sangat Tinggi & 61 & $61 \%$ \\
2 & $21-25$ & Tinggi & 38 & $38 \%$ \\
3 & $16-20$ & Sedang & 1 & $1 \%$ \\
4 & $11-15$ & Rendah & 0 & $0 \%$ \\
5 & $6-10$ & Sangat Rendah & 0 & $0 \%$ \\
Total & & & 100 & $100 \%$ \\
\hline
\end{tabular}

Berdasarkan tabel 3 dapat diketahui bahwa mahasiswa prodi S1 Pendidikan Ekonomi Angkatan 2017 memiliki penggunaan media sosial dengan kategori sangat tinggi sebanyak 61 mahasiswa dengan persentase sebesar $61 \%$. Selain itu, sebanyak 38 mahasiswa masuk dalam kategori tinggi dengan persentase sebesar 38\%. Untuk kategori sedang terdapat 1 mahasiswa dengan persentase sebesar $1 \%$. Sedangkan untuk kategori rendah dan sangat rendah tidak terdapat mahasiswa yang termasuk pada kategori tersebut. Hal ini dapat dibuktikan dari nilai distribusi frekuensi yang menunjukkan bahwa nilai frekuensi untuk variabel penggunaan media sosial yaitu 0 dengan persentase $0 \%$. Sehingga, dari data distribusi frekuensi tersebut maka dapat disimpulkan bahwa sebagian besar mahasiswa prodi S1 Pendidikan Ekonomi Angkatan 2017 Universitas Negeri Malang memiliki tingkat penggunaan media sosial yang tergolong sangat tinggi.

\subsubsection{Minat Berwirausaha (Y)}

Nilai Minimum : 18

Nilai Maximum : 30

Mean : 26,29

Simpangan Baku / Standard Deviasi : 2,935

Tabel 4. Distribusi Frekuensi Minat Berwirausaha (Y)

\begin{tabular}{lllll}
\hline No. & Kelas Interval & Kategori & Frekuensi & Persentase \\
\hline 1 & $26-30$ & Sangat Tinggi & 57 & $57 \%$ \\
2 & $21-25$ & Tinggi & 40 & $40 \%$ \\
3 & $16-20$ & Sedang & 3 & $3 \%$ \\
4 & $11-15$ & Rendah & 0 & $0 \%$ \\
5 & $6-10$ & Sangat Rendah & 0 & $0 \%$ \\
Total & & & 100 & $100 \%$ \\
\hline
\end{tabular}

Berdasarkan tabel 4 dapat diketahui bahwa mahasiswa prodi S1 Pendidikan Ekonomi Angkatan 2017 memiliki minat berwirausaha dengan kategori sangat tinggi sebanyak 57 mahasiswa dengan persentase sebesar $57 \%$. Selain itu, sebanyak 40 mahasiswa masuk dalam kategori tinggi dengan persentase sebesar $40 \%$. Untuk kategori sedang terdapat 3 mahasiswa dengan persentase sebesar 3\%. Sedangkan untuk kategori rendah dan sangat rendah tidak 
terdapat mahasiswa yang termasuk pada kategori tersebut. Hal ini dapat dibuktikan dari nilai distribusi frekuensi yang menunjukkan bahwa nilai frekuensi

untuk variabel minat berwirausaha yaitu 0 dengan persentase $0 \%$. Sehingga, dari data distribusi frekuensi tersebut maka dapat disimpulkan bahwa sebagian besar mahasiswa prodi S1 Pendidikan Ekonomi Angkatan 2017 Universitas Negeri Malang memiliki tingkat minat berwirausaha yang tergolong sangat tinggi.

\subsubsection{Uji Normalitas}

Tabel 5. Uji Normalitas

One-Sample Kolmogorov-Smirnov Test

\begin{tabular}{lll} 
& & Unstandardized Residual \\
\hline $\mathrm{N}$ & & 100 \\
\hline Normal Parametersa,b & Mean & 0,0000000 \\
& Std. Deviation & 1,69292560 \\
Most Extreme & Absolute & 0,079 \\
Differences & Positive & 0,079 \\
& Negative & $-0,047$ \\
Test Statistic & & 0,079 \\
Asymp. Sig. (2-tailed) &, $129^{c}$ \\
\hline
\end{tabular}

Berdasarkan tabel 5 hasil uji normalitas dengan kriteria Kolmogorov-Smirnov diperoleh nilai probabilitas Asymp.sig.(2-tailed) > nilai signifikansi 0,05 yaitu 0,129>0,05, sehingga dalam hal ini dapat dikatakan data penelitian terdistribusi secara normal.

\subsubsection{Uji Multikolinearitas}

Tabel 6. Uji Multikolinearitas

\begin{tabular}{|c|c|c|c|c|c|c|c|c|}
\hline \multicolumn{9}{|c|}{ Coefficients ${ }^{a}$} \\
\hline \multirow{3}{*}{\multicolumn{2}{|c|}{ Model }} & \multirow{2}{*}{\multicolumn{2}{|c|}{$\begin{array}{l}\text { Unstandardized } \\
\text { Coefficients }\end{array}$}} & \multirow{3}{*}{$\begin{array}{l}\begin{array}{l}\text { Standar } \\
\text { dized } \\
\text { Coeffici } \\
\text { ents }\end{array} \\
\text { Beta } \\
\end{array}$} & \multirow[b]{3}{*}{$\mathrm{t}$} & \multirow[b]{3}{*}{ Sig. } & \multirow{2}{*}{\multicolumn{2}{|c|}{$\begin{array}{l}\text { Collinearity } \\
\text { Statistics }\end{array}$}} \\
\hline & & & & & & & & \\
\hline & & B & $\begin{array}{l}\text { Std. } \\
\text { Error }\end{array}$ & & & & $\begin{array}{l}\text { Tolera } \\
\text { nce }\end{array}$ & VIF \\
\hline & (Constant) & 3,489 & 2,046 & & 1,706 & 0,091 & & \\
\hline & $\begin{array}{l}\text { Motivasi_Berwi } \\
\text { rausaha }\end{array}$ & 0,352 & 0,049 & 0,566 & 7,152 & 0,000 & 0,554 & 1,806 \\
\hline & $\begin{array}{l}\text { Pembelajaran } \\
\text { Kewirausahaan }\end{array}$ & 0,136 & 0,064 & 0,151 & 2,137 & 0,035 & 0,699 & 1,432 \\
\hline & $\begin{array}{l}\text { Penggunaan_M } \\
\text { edia_Sosial }\end{array}$ & 0,250 & 0,071 & 0,245 & 3,512 & 0,001 & 0,715 & 1,400 \\
\hline
\end{tabular}

a. Dependent Variable: Minat_Berwirausaha

Dapat dilihat dari tabel 6 untuk hasil nilai VIF dari masing - masing variabel bebas yang terdiri atas motivasi berwirausaha (X1), pembelajaran kewirausahaan (X2) dan penggunaan 
media sosial (X3) memiliki nilai VIF kurang dari 10 (VIF < 10), sedangkan untuk hasil nilai tolerance pada masing - masing variabel bebas memiliki nilai lebih dari 0,10 (tolerance $>0,10$ ). Sehingga, dalam hal ini dapat disimpulkan bahwa model regresi yang terdapat dalam penelitian ini dikatakan baik karena tidak terjadi masalah multikolinearitas.

\subsubsection{Uji Heteroskedastisitas}

Tabel 7. Uji Heteroskedastisitas

\begin{tabular}{|c|c|c|c|c|c|c|}
\hline \multicolumn{7}{|c|}{ Coefficients $^{a}$} \\
\hline \multirow{2}{*}{\multicolumn{2}{|c|}{ Model }} & \multicolumn{2}{|c|}{$\begin{array}{l}\text { Unstandardized } \\
\text { Coefficients }\end{array}$} & \multirow{2}{*}{$\begin{array}{l}\text { Standardized } \\
\text { Coefficients }\end{array}$} & \multirow[b]{2}{*}{$\mathrm{t}$} & \multirow[b]{2}{*}{ Sig. } \\
\hline & & B & $\begin{array}{l}\text { Std. } \\
\text { Error }\end{array}$ & & & \\
\hline 1 & (Constant) & 2,703 & 1,269 & & 2,129 & 0,036 \\
\hline & Motivasi_Berwirausaha & $-0,034$ & 0,031 & $-0,152$ & $-\overline{1} 126$ & 0,263 \\
\hline & Pembelajaran_Kewirausahaan & 0,019 & 0,040 & 0,058 & 0,485 & 0,629 \\
\hline & Penggunaan_Media_Sosial & $-0,032$ & 0,044 & $-0,085$ & $\overline{0}, 718$ & 0,474 \\
\hline
\end{tabular}

a. Dependent Variable: Abs_Res

Dari hasil uji Glejser pada tabel 7 dapat dinyatakan bahwa nilai signifikansi pada masingmasing variabel bebas yang terdiri atas motivasi berwirausaha $\left(\mathrm{X}_{1}\right)$, pembelajaran kewirausahaan $\left(\mathrm{X}_{2}\right)$ dan penggunaan media sosial $\left(\mathrm{X}_{3}\right)$ memiliki nilai signifikansi lebih dari 0,05. Sehingga dalam hal ini dapat disimpulkan bahwa tidak terjadi masalah heteroskedastisitas pada model regresi dalam penelitian ini.

\subsubsection{Analisis Regresi Linear Berganda}

Tabel 8. Analisis Regresi Linear Berganda

\begin{tabular}{|c|c|c|c|c|c|c|}
\hline \multicolumn{7}{|c|}{ Coefficients $^{a}$} \\
\hline \multirow{2}{*}{\multicolumn{2}{|c|}{ Model }} & \multicolumn{2}{|c|}{$\begin{array}{l}\text { Unstandardized } \\
\text { Coefficients }\end{array}$} & \multirow{2}{*}{$\begin{array}{l}\text { Standardized } \\
\text { Coefficients } \\
\text { Beta } \\
\end{array}$} & \multirow[b]{2}{*}{$\mathrm{t}$} & \multirow[b]{2}{*}{ Sig. } \\
\hline & & B & $\begin{array}{l}\text { Std. } \\
\text { Error }\end{array}$ & & & \\
\hline \multirow[t]{4}{*}{1} & (Constant) & 3,489 & 2,046 & & 1,706 & 0,091 \\
\hline & Motivasi_Berwirausaha & 0,352 & 0,049 & 0,566 & 7,152 & 0,000 \\
\hline & Pembelajaran_Kewirausahaan & 0,136 & 0,064 & 0,151 & 2,137 & 0,035 \\
\hline & Penggunaan_Media_Sosial & 0,250 & 0,071 & 0,245 & 3,512 & 0,001 \\
\hline
\end{tabular}

a. Dependent Variable: Minat_Berwirausaha

Berdasarkan tabel 8, dapat disimpulkan bahwa variabel X1 motivasi berwirausaha memiliki nilai koefisien regresi sebesar 0,352 , variabel X2 pembelajaran kewirausahaan 
memiliki nilai koefisien regresi sebesar 0,136, sedangkan untuk variabel X3 penggunaan media sosial memiliki nilai koefisien regresi sebesar 0,250 .

\subsubsection{Uji Parsial (Uji T)}

Tabel 9. Uji Parsial (Uji T)

\begin{tabular}{|c|c|c|c|c|c|c|}
\hline \multicolumn{7}{|c|}{ Coefficients $^{\mathrm{a}}$} \\
\hline & & \multicolumn{2}{|c|}{$\begin{array}{l}\text { Unstandardized } \\
\text { Coefficients }\end{array}$} & \multirow{2}{*}{$\begin{array}{l}\text { Standardized } \\
\text { Coefficients } \\
\text { Beta }\end{array}$} & \multirow[b]{2}{*}{$\mathrm{t}$} & \multirow[b]{2}{*}{ Sig. } \\
\hline \multicolumn{2}{|c|}{ Model } & B & $\begin{array}{l}\text { Std. } \\
\text { Error }\end{array}$ & & & \\
\hline \multirow[t]{4}{*}{1} & (Constant) & 3,489 & 2,046 & & 1,706 & 0,091 \\
\hline & Motivasi_Berwirausaha & 0,352 & 0,049 & 0,566 & 7,152 & 0,000 \\
\hline & Pembelajaran_Kewirausahaan & 0,136 & 0,064 & 0,151 & 2,137 & 0,035 \\
\hline & Penggunaan_Media_Sosial & 0,250 & 0,071 & 0,245 & 3,512 & 0,001 \\
\hline
\end{tabular}

a. Dependent Variable: Minat_Berwirausaha

Berdasarkan tabel 9 masing - masing variabel bebas baik itu X1, X2 dan X3 memiliki nilai $r$ hitung yg lebih besar dari nilai $r$ tabel (rhitung $>$ rtabel). Sedangkan untuk nilai signifikansi yang diperoleh pada masing variabel bebas memiliki nilai signifikansi kurang dari 0,05 (sig < 0,05 ) sehingga dalam hal ini dapat dikatakan bahwa hasil uji hipotesis pada masing - masing variabel bebas baik itu X1, X2 dan X3 yaitu Ho ditolak dan Ha diterima. Jadi dapat diartikan bahwa masing - masing variabel bebas yang terdiri atas motivasi berwirausaha, pembelajaran kewirausahaan dan penggunaan media sosial berpengaruh terhadap minat berwirausaha pada mahasiswa S1 Pendidikan Ekonomi Angkatan 2017 Universitas Negeri Malang.

\subsubsection{Uji Simultan ( Uji F)}

Tabel 10. Uji Simultan (Uji F)

\begin{tabular}{lllllll}
\hline \multicolumn{7}{c}{ ANOVA $^{\text {a }}$} \\
\hline Model & & Sum of Squares & df & Mean Square & F & Sig. \\
\hline 1 & Regression & 568,856 & 3 & 189,619 & 64,157 &, $000^{\mathrm{b}}$ \\
& Residual & 283,734 & 96 & 2,956 & & \\
& Total & 852,590 & 99 & & & \\
\hline
\end{tabular}

a. Dependent Variable: Minat_Berwirausaha

b. Predictors: (Constant), Penggunaan_Media_Sosial,

Pembelajaran_Kewirausahaan, Motivasi_Berwirausaha

Berdasarkan tabel 10 secara keseluruhan nilai variabel bebas baik itu X1, X2 maupun X3 memperoleh nilai $r$ hitung yg lebih besar dari nilai $r$ tabel (rhitung $>$ rtabel). Sedangkan untuk nilai signifikansi yang diperoleh kurang dari 0,05 (sig < 0,05) sehingga dalam hal ini dapat dikatakan bahwa hasil uji hipotesis untuk seluruh variabel bebas baik itu X1, X2 dan X3 yaitu Ho ditolak dan Ha diterima. Oleh karena itu dapat diartikan bahwa secara keseluruhan variabel bebas yang terdiri atas motivasi berwirausaha, pembelajaran kewirausahaan dan penggunaan media sosial berpengaruh terhadap minat berwirausaha pada mahasiswa S1 Pendidikan Ekonomi Angkatan 2017 Universitas Negeri Malang. 


\subsubsection{Koefisien Determinasi (R2)}

Tabel 11. Koefisien Determinasi $\left(R^{2}\right)$

\begin{tabular}{lllll}
\hline \multicolumn{5}{c}{ Model Summary } \\
\hline & & & Adjusted & $\begin{array}{l}\text { Std. } \\
\text { Error of } \\
\text { the }\end{array}$ \\
Model & $\mathrm{R}$ & R Square & Square & Estimate \\
\hline 1 &, $817^{\mathrm{a}}$ & 0,667 & 0,657 & 1,719 \\
\hline
\end{tabular}

a. Predictors: (Constant), Penggunaan_Media_Sosial,

Pembelajaran_Kewirausahaan, Motivasi_Berwirausaha

Dapat dilihat dari tabel 11 nilai koefisien determinasi diperoleh sebesar 0,667. Hal ini dapat diartikan bahwa variabel motivasi berwirausaha, pembelajaran kewirausahaan, dan penggunaan media sosial memiliki proporsi pengaruh terhadap minat berwirausaha mahasiswa S1 Pendidikan Ekonomi angkatan 2017 sebesar 66,7\%, sedangkan sisanya sebesar 33,3\% (100 \% - 66,7\%) dipengaruhi oleh variabel - variabel lain diluar penelitian.

\subsubsection{Sumbangan Efektif (SE)}

Tabel 12. Sumbangan Efektif (SE)

\begin{tabular}{|c|c|c|c|c|}
\hline Variabel & $\begin{array}{c}\text { Zero } \\
\text { order }\end{array}$ & Beta & $\begin{array}{c}\text { Perhitungan (Zero } \\
\text { Order } \times \text { Beta } \times \\
100 \% \text { ) }\end{array}$ & $\begin{array}{c}\text { Hasil } \\
\text { Sumbangan } \\
\text { Efektif (SE) }\end{array}$ \\
\hline $\begin{array}{l}\text { Motivasi Berwirausaha } \\
\left(\mathrm{X}_{1}\right)\end{array}$ & 0,779 & 0,566 & $0,779 \times 0,566 \times 100 \%$ & $44,091 \%$ \\
\hline $\begin{array}{l}\text { Pembelajaran } \\
\text { Kewirausahaan }\left(\mathrm{X}_{2}\right)\end{array}$ & 0,538 & 0,151 & $0,538 \times 0,151 \times 100 \%$ & $8,124 \%$ \\
\hline $\begin{array}{l}\text { Penggunaan Media Sosial } \\
\left(\mathrm{X}_{3}\right)\end{array}$ & 0,594 & 0,245 & $0,594 \times 0,245 \times 100 \%$ & $14,553 \%$ \\
\hline \multicolumn{4}{|c|}{ Total Sumbangan Efektif (SE) } & $66,768 \%$ \\
\hline
\end{tabular}

Berdasarkan tabel 12 dapat diketahui bahwa sumbangan efektif untuk variabel motivasi berwirausaha terhadap minat berwirausaha sebesar 44,091\%. Sumbangan efektif untuk variabel pembelajaran kewirausahaan terhadap minat berwirausaha diperoleh hasil sebesar $8,124 \%$. Sedangkan sumbangan efektif untuk variabel penggunaan media sosial terhadap minat berwirausaha sebesar $14,553 \%$. Sehingga dalam hal ini dapat disimpulkan bahwa variabel motivasi berwirausaha (X1) memiliki pengaruh yang lebih dominan terhadap minat berwirausaha pada mahasiswa S1 Pendidikan Ekonomi Angkatan 2017 yaitu sebesar 44,091\%. 


\subsection{Pembahasan}

\subsubsection{Pengaruh Motivasi Berwirausaha Terhadap Minat Berwirausaha Pada Mahasiswa Prodi S1 Pendidikan Ekonomi Angkatan 2017 Universitas Negeri Malang}

Berdasarkan penelitian yang telah dilakukan terkait pengaruh motivasi berwirausaha terhadap minat berwirausaha pada mahasiswa Program Studi S1 Pendidikan Ekonomi Angkatan 2017 Universitas Negeri Malang diperoleh hasil bahwa terdapat pengaruh yang signifikan antara motivasi berwirausaha terhadap minat berwirausaha. Sehingga dalam penelitian ini minat berwirausaha dapat timbul salah satunya yaitu karena adanya motivasi berwirausaha pada diri individu. Penelitian ini juga diperkuat dengan penelitian yang pernah dilakukan oleh Wijayangka, dkk. (2018) yang dalam hasil penelitiannya menunjukkan bahwa terdapat pengaruh antara motivasi berwirausaha terhadap minat berwirausaha. Selain itu terdapat juga penelitian dari Alfaruk (2016) yang dalam hasil penelitiannya menunjukkan bahwa motivasi berwirausaha berpengaruh terhadap minat berwirausaha.

Motivasi dalam berwirausaha khususnya pada mahasiswa biasanya terdiri atas motivasi intrinsik dan motivasi ekstrinsik. Motivasi intrinsik yaitu motivasi yang berasal dari dalam diri individu. Motivasi intrinsik ini memiliki peranan penting dalam menumbuhkan minat berwirausaha. Pernyataan tersebut sesuai dengan yang dikemukakan oleh (Iswandari, 2013). Sehingga dengan adanya motivasi intrinsik yang dimiliki oleh mahasiswa dapat memberikan dorongan dari dalam diri mahasiswa untuk minat berwirausaha. Adanya motivasi intrinsik ini maka seorang mahasiswa akan melakukan segala upaya atau usaha untuk mewujudkan keinginannya, salah satunya yaitu dengan terus mengembangkan minat berwirausaha pada dirinya melalui berbagai cara yang dapat dilakukannya misalnya yaitu selalu berlatih dan belajar tentang bagaimana dapat berwirausaha dengan baik.

Dalam penelitian ini motivasi intrinsik yaitu meliputi adanya cita - cita yang dimiliki oleh mahasiswa untuk menjadi seorang wirausahawan sukses, adanya dorongan dan kebutuhan dalam berwirausaha serta adanya pemikiran yang kreatif, inovatif dan bekerja keras. Pada saat ini banyak dari mahasiswa khususnya mahasiswa S1 Pendidikan Ekonomi Angkatan 2017 yang mulai tertarik untuk berwirausaha hal ini dikarenakan adanya hasrat dan keinginan untuk berhasil dan adanya dorongan untuk dapat membantu orang tua dalam meringankan kebutuhan biaya hidup, misalnya dalam hal memenuhi keperluan kuliah. Selain itu mereka juga tertarik untuk minat berwirausaha dikarenakan adanya cita - cita yang dimilikinya untuk menjadi seorang wirausahawan sukses di masa depan.

Selain motivasi intrinsik terdapat pula motivasi ekstrinsik. Motivasi ekstrinsik yaitu motivasi yang berasal dari luar diri individu. Motivasi ekstrinsik ini biasanya dapat timbul karena adanya pengaruh dari lingkungan sekitar baik itu dari lingkungan keluarga maupun lingkungan masyarakat. Motivasi ekstrinsik dalam hal ini memiliki peranan penting juga dalam menumbuhkan minat berwirausaha pada setiap individu khususnya mahasiswa S1 Pendidikan Ekonomi Angkatan 2017. Seperti pernyataan yang dikemukakan oleh Syarifuddin, dkk.(2017) yang menyatakan bahwa lingkungan juga dapat memberikan dorongan pada individu untuk tertarik berwirausaha. Sehingga dalam hal ini lingkungan di sekitar mahasiswa dapat mendukung tumbuhnya minat berwirausaha. Salah satu contohnya yaitu seorang mahasiswa yang bersosialisasi dan bergaul dengan orang - orang yang sukses berwirausaha, maka hal ini 
dapat memberikan dorongan atau motivasi dalam menumbuhkan minat berwirausaha pada dirinya. Sehingga dalam hal ini dapat disimpulkan bahwa motivasi baik itu motivasi intrinsik maupun ekstrinsik dapat mempengaruhi minat berwirausaha pada mahasiswa. Hal ini dapat dibuktikan dari hasil penelitian yang diperoleh bahwa motivasi berwirausaha memberikan pengaruh terhadap minat berwirausaha pada mahasiswa S1 Pendidikan Ekonomi Angkatan 2017 Universitas Negeri Malang.

\subsubsection{Pengaruh Pembelajaran Kewirausahaan Terhadap Minat Berwirausaha Pada Mahasiswa Prodi S1 Pendidikan Ekonomi Angkatan 2017 Universitas Negeri Malang}

Berdasarkan penelitian yang telah dilakukan terkait pengaruh pembelajaran kewirausahaan terhadap minat berwirausaha pada mahasiswa Program Studi S1 Pendidikan Ekonomi Angkatan 2017 Universitas Negeri Malang diperoleh hasil bahwa terdapat pengaruh yang signifikan antara pembelajaran kewirausahaan terhadap minat berwirausaha. Sehingga dalam penelitian ini salah satu faktor yang mempengaruhi minat berwirausaha pada mahasiswa S1 Pendidikan Ekonomi Angkatan 2017 adalah pembelajaran kewirausahaan. Penelitian ini juga diperkuat dengan penelitian yang pernah dilakukan oleh Amanda (2018) yang dalam hasil penelitiannya menunjukkan bahwa terdapat pengaruh antara pembelajaran kewirausahaan terhadap minat berwirausaha. Selain itu terdapat juga penelitian dari Listiawati,dkk. (2020) yang dalam hasil penelitiannya menyatakan bahwa pembelajaran kewirausahaan dapat mempengaruhi minat berwirausaha. Selain itu penelitian dari Aini (2015) juga memperoleh hasil bahwa pembelajaran kewirausahaan dapat memberikan pengaruh terhadap minat berwirausaha.

Pembelajaran kewirausahaan yang pernah diterima oleh mahasiswa di suatu lembaga pendidikan khususnya perguruan tinggi dapat mempengaruhi minat berwirausaha suatu individu. Seperti pernyataan yang dikemukakan oleh Listiawati,dkk. (2020) yang menyatakan bahwa perguruan tinggi juga memiliki peranan yang penting dalam menumbuhkan minat berwirausaha pada mahasiswa, oleh karena itu untuk menumbuhkan minat berwirausaha pada mahasiswa maka suatu perguruan tinggi dapat memberikan mata kuliah kewirausahaan. Melalui mata kuliah kewirausahaan ini seorang tenaga pendidik atau dosen akan memberikan pembelajaran terkait kewirausahaan. Sehingga dengan adanya pembelajaran kewirausahaan yang diberikan oleh dosen kepada mahasiswa dapat membuat mereka banyak menerima berbagai ilmu terkait dunia wirausaha dan pada akhirnya juga dapat membentuk jiwa wirausaha pada mahasiswa. Oleh karena itu dalam hal ini perguruan tinggi juga akan berperan penting dalam membentuk jiwa wirausaha dan menumbuhkan minat berwirausaha pada mahasiswa.

Melalui pembelajaran kewirausahaan ini mahasiswa akan banyak diajarkan mengenai ilmu-ilmu kewirausahaan maupun praktik berwirausaha. Selain itu dalam pembelajaran kewirausahan ini mahasiswa akan diajarkan mengenai berbagai keterampilan-keterampilan dalam berwirausaha. Sehingga melalui pembelajaran kewirausahaan ini maka dapat menumbuhkan rasa semangat dan dorongan untuk minat berwirausaha. Adanya pembelajaran kewirausahaan akan sangat menguntungkan bagi mahasiswa hal ini dikarenakan dengan adanya pembelajaran kewirausahaan ini maka seorang mahasiswa akan dibekali berbagai ilmu serta keterampilan dalam berwirausaha. Sehingga nantinya mereka dapat membuka usaha dengan baik. Oleh karena itu, dengan adanya pembelajaran kewirausahaan yang terdapat 
dalam suatu perguruan tinggi ini dapat memberikan dorongan atau semangat pada mahasiswa untuk berwirausaha, mengembangkan pola pikir pada mahasiswa untuk dapat berpikir kreatif dan inovatif serta melalui pembelajaran kewirausahaan ini mahasiswa juga dapat mengembangkan keterampilan berwirausaha melalui praktik yang diberikan pada saat pembelajaran. Sehingga melalui pembelajaran kewirausahaan ini nantinya dapat membentuk jiwa kewirausahaan pada mahasiswa khususnya pada mahasiswa S1 Pendidikan Ekonomi Angkatan 2017. Hal ini dapat dibuktikan dari hasil penelitian yang diperoleh bahwa pembelajaran kewirausahaan berpengaruh terhadap minat berwirausaha pada mahasiswa S1 Pendidikan Ekonomi Angkatan 2017 Universitas Negeri Malang.

\subsubsection{Pengaruh Penggunaan Media Sosial Terhadap Minat Berwirausaha Pada Mahasiswa Prodi S1 Pendidikan Ekonomi Angkatan 2017 Universitas Negeri Malang}

Berdasarkan penelitian yang telah dilakukan terkait pengaruh penggunaan media sosial terhadap minat berwirausaha pada mahasiswa Program Studi S1 Pendidikan Ekonomi Angkatan 2017 Universitas Negeri Malang diperoleh hasil bahwa terdapat pengaruh yang signifikan antara penggunaan media sosial terhadap minat berwirausaha. Sehingga pada penelitian ini yang menjadi salah satu faktor dalam mempengaruhi minat berwirausaha pada mahasiswa S1 Pendidikan Ekonomi Angkatan 2017 adalah penggunaan media sosial. Penelitian ini juga diperkuat dengan penelitian yang pernah dilakukan oleh Sahroh (2018) yang dalam hasil penelitiannya menunjukkan bahwa terdapat pengaruh yang signifikan antara penggunaan media sosial terhadap minat berwirausaha.

Pada saat ini banyak kalangan anak muda yang telah memiliki media sosial khususnya di kalangan mahasiswa. Berbagai media sosial yang mereka miliki mulai dari Instagram, WhatsApp, Facebook dan lain-lain. Mereka menggunakan media sosial sebagai sarana komunikasi dengan sesama pengguna maupun sebagai sarana untuk mencari informasi. Dengan munculnya berbagai media sosial ini membuat komunikasi dan menemukan berbagai informasi menjadi lebih mudah di akses. Penggunaan media sosial yang lebih praktis dan mudah diakses membuat banyak mahasiswa mulai tertarik untuk berwirausaha. Seperti pernyataan yang dikemukakan oleh Rahayu \& Laela (2018) yang menyatakan bahwa jika semakin tinggi tingkat penggunaan media sosial pada mahasiswa maka semakin tinggi juga tingkat kewirausahaan mereka. Sehingga dalam hal ini dapat dikatakan bahwa penggunaan media sosial dapat meningkatkan minat berwirausaha pada mahasiswa. Selain itu media sosial yang digunakan secara optimal dapat menumbuhkan minat berwirausaha pada mahasiswa. Pernyataan tersebut sesuai dengan yang dikemukakan oleh (Prasetio, 2020). Sehingga dalam hal ini dengan adanya penggunaan media sosial secara optimal seorang individu dapat dengan mudah mencari berbagai informasi menarik terkait dunia wirausaha maupun melihat berbagai peluang usaha yang sedang banyak diminati oleh masyarakat. Jadi, dengan adanya penggunaan media sosial secara optimal pada akhirnya akan semakin membuka peluang yang besar untuk menumbuhkan minat berwirausaha pada mahasiswa.

Melalui media sosial mahasiswa dapat mengakses berbagai informasi khususnya terkait dunia kewirausahaan dengan mudah. Selain itu, dengan adanya media sosial ini mahasiswa juga dapat memberikan berbagai informasi dengan praktis yaitu bisa melalui berbagai fitur fitur yang ada di dalamnya salah satunya yaitu fitur berbagi status yang dimiliki oleh WhatsApp, Facebook maupun Instagram. Sehingga dengan adanya kemudahan dalam 
menggunakan media sosial ini membuat mahasiswa khususnya mahasiswa S1 Pendidikan Ekonomi Angkatan 2017 mulai tertarik untuk berwirausaha. Hal ini dapat dibuktikan dari hasil penelitian yang diperoleh bahwa penggunaan media sosial berpengaruh terhadap minat berwirausaha pada mahasiswa S1 Pendidikan Ekonomi Angkatan 2017 Universitas Negeri Malang.

\subsubsection{Pengaruh Motivasi Berwirausaha, Pembelajaran Kewirausahaan dan Penggunaan Media Sosial Terhadap Minat Berwirausaha Pada Mahasiswa Prodi S1 Pendidikan Ekonomi Angkatan 2017 Universitas Negeri Malang}

Berdasarkan penelitian yang telah dilakukan terkait pengaruh motivasi berwirausaha, pembelajaran kewirausahaan dan penggunaan media sosial terhadap minat berwirausaha pada mahasiswa Program Studi S1 Pendidikan Ekonomi Angkatan 2017 Universitas Negeri Malang diperoleh hasil bahwa motivasi berwirausaha, pembelajaran kewirausahaan dan penggunaan media sosial dapat memberikan pengaruh terhadap minat berwirausaha pada mahasiswa S1 Pendidikan Ekonomi Angkatan 2017. Sehingga dalam penelitian ini secara keseluruhan baik itu motivasi berwirausaha, pembelajaran kewirausahaan dan penggunaan media sosial dapat mempengaruhi minat berwirausaha.

Motivasi dapat mendorong mahasiswa untuk minat berwirausaha. Motivasi ini dapat berasal dari lingkungan sekitar maupun dari dalam diri individu. Seperti pernyataan yang dikemukakan oleh Iswandari (2013) yang menyatakan bahwa motivasi merupakan salah satu faktor yang memiliki peran penting dalam mendorong minat berwirausaha. Motivasi ini dapat berasal dari dalam diri maupun dari lingkungan luar. Adanya motivasi intrinsik atau motivasi yang berasal dari dalam diri ini membuat mahasiswa akan terdorong untuk minat berwirausaha. Dorongan ini dapat timbul dikarenakan adanya cita-cita yang dimiliki oleh mahasiswa untuk menjadi seorang wirausahawan maupun adanya keinginan untuk dapat membantu orang tua dalam meringankan biaya hidup salah satunya dalam hal memenuhi keperluan kuliah. Selain motivasi intrinsik terdapat pula motivasi berwirausaha yang dipengaruhi oleh lingkungan sekitar atau yang biasa disebut sebagai motivasi ekstrinsik. Motivasi ekstrinsik ini dapat timbul karena adanya pengaruh dari luar atau dari lingkungan sekitar. Salah satu contoh motivasi berwirausaha yang dipengaruhi oleh lingkungan sekitar yaitu seorang mahasiswa yang berteman dan sering bersosilisasi dengan orang - orang yang berwirausaha maka, ada kecenderungan individu atau mahasiswa tersebut akan ikut terdorong untuk berwirausaha. Sehingga dalam hal ini maka, motivasi berwirausaha baik itu yang bersifat intrinsik maupun ekstrinsik dapat memberikan pengaruh terhadap minat berwirausaha pada mahasiswa khususnya mahasiswa S1 Pendidikan Ekonomi Angkatan 2017.

Salah satu faktor yang juga dapat memberikan motivasi untuk minat berwirausaha pada mahasiswa khususnya mahasiswa S1 Pendidikan Ekonomi angkatan 2017 yaitu karena adanya pembelajaran kewirausahaan yang pernah dipelajari pada semester enam lalu. Dalam pembelajaran kewirausahaan ini mahasiswa akan diajarkan dengan berbagai ilmu terkait kewirausahaan. Selain itu pada pembelajaran kewirausahaan ini mahasiswa juga akan diberikan keterampilan-keterampilan dalam berwirausaha. Adanya pembelajaran kewirausahaan ini dapat memberikan dorongan maupun semangat kepada mahasiswa untuk minat berwirausaha serta dapat mengembangkan pola pikir untuk selalu berpikir kreatif dan inovatif. Sehingga melalui pembelajaran kewirausahaan ini akan dapat membentuk jiwa 
kewirausahaan pada mahasiswa serta dapat menimbulkan motivasi dari dalam dirinya untuk minat berwirausaha

Selain pembelajaran kewirausahaan terdapat pula penggunaan media sosial yang dapat memberikan motivasi kepada mahasiswa khususnya mahasiswa S1 Pendidikan Ekonomi Angkatan 2017 untuk minat berwirausaha. Dengan adanya media sosial ini mahasiswa dapat dengan mudah memperoleh berbagai informasi terkait kewirausahaan baik itu seputar peluang usaha maupun berbagai tips dalam menjalankan suatu bisnis. Selain itu dengan menggunakan media sosial ini mahasiswa juga dapat saling berbagi informasi dengan sesama pengguna melalui berbagai fitur-fitur yang telah disediakan. Dengan adanya kemudahan dalam menggunakan media sosial maka dapat memberikan dorongan atau motivasi pada individu untuk berwirausaha.

Sehingga dengan adanya motivasi berwirausaha, bekal ilmu maupun keterampilan yang didapatkan dalam pembelajaran kewirausahaan, serta didukung dengan adanya kemudahan dalam penggunaan media sosial untuk dapat mencari dan berbagi informasi terkait dunia wirausaha, maka hal ini dapat membentuk jiwa wirausaha dan menumbuhkan minat berwirausaha pada mahasiswa S1 Pendidikan Ekonomi Angkatan 2017. Jadi, dari hasil penelitian ini secara keseluruhan dapat disimpulkan bahwa motivasi berwirausaha, pembelajaran kewirausahaan dan penggunaan media sosial dapat memberikan pengaruh terhadap minat berwirausaha pada mahasiswa S1 Pendidikan Ekonomi Angkatan 2017 Universitas Negeri Malang.

\section{Simpulan}

\subsection{Kesimpulan}

Berdasarkan hasil penelitian dan pembahasan yang telah dijabarkan di atas, maka dapat disimpulkan yaitu, (1) motivasi berwirausaha dapat mempengaruhi minat berwirausaha pada mahasiswa S1 Pendidikan Ekonomi angkatan 2017 Universitas Negeri Malang. (2) Pembelajaran kewirausahaan dapat mempengaruhi minat berwirausaha pada mahasiswa S1 Pendidikan Ekonomi Angkatan 2017 Universitas Negeri Malang. (3) Penggunaan media sosial dapat mempengaruhi minat berwirausaha pada mahasiswa S1 Pendidikan Ekonomi Angkatan 2017 Universitas Negeri Malang. (4) Motivasi berwirausaha, pembelajaran kewirausahaan dan penggunaan media sosial secara keseluruhan dapat mempengaruhi minat berwirausaha pada mahasiswa S1 Pendidikan Ekonomi Angkatan 2017 Universitas Negeri Malang.

\subsection{Saran}

Dari kesimpulan yang telah dijabarkan di atas maka terdapat beberapa saran yang dapat disampaikan diantaranya yaitu sebagai berikut: (1) Bagi Mahasiswa yaitu seorang mahasiswa yang memiliki motivasi berwirausaha hendaknya dapat terus memperkuat motivasinya tersebut agar nantinya dapat menjadi wirausahawan. Selain itu hendaknya mahasiswa dapat menggunakan media sosial secara optimal, sehingga nantinya media sosial tersebut dapat memberikan dampak positif untuk mengembangkan minat kewirausahaannya. (2) Bagi Universitas Negeri Malang yaitu Universitas Negeri Malang hendaknya dapat lebih sering mengadakan berbagai acara terkait kewirausahaan misalnya yaitu seminar yang berkaitan dengan wirausaha. Dengan mengadakan berbagai acara yang berkaitan dengan kewirausahaan ini akan dapat dijadikan penunjang bagi mahasiswa dalam memperoleh ilmu kewirausahaan. 
Sehingga mahasiswa akan dapat memperoleh ilmu kewirausahaan dari kegiatan pembelajaran kewirausahaan di kelas maupun dari berbagai kegiatan terkait kewirausahaan yang diadakan oleh Universitas Negeri Malang. Jadi diharapkan nantinya mahasiswa dapat lebih memiliki wawasan yang luas tentang ilmu berwirausaha. Pada akhirnya mereka dapat berwirausaha dengan dibekali ilmu kewirausahaan yang pernah diperolehnya pada saat menempuh pendidikan di perguruan tinggi.

\section{Daftar Rujukan}

Alfaruk, M.H. (2016). Pengaruh Pemanfaatan Sosial Media, Motivasi, dan Pengetahuan Terhadap Minat Berwirausaha Pada Mahasiswa Ekonomi di Universitas Muhammadiyah Sidoarjo. Jurnal Ekonomi Pendidikan dan Kewirausahaan, 4(2), $164 \quad$ - $172 . \quad$ Dari https://journal.unesa.ac.id/index.php/jepk/article/view/772.

Alfianto, E.A. (2012). Kewirausahaan : Sebuah Kajian Pengabdian Kepada Masyarakat. Jurnal Heritage, 1(2), 33 - 42. Dari https://jurnal.yudharta.ac.id/v2/index.php/HERITAGE/article/view/837.

Aini, Y. (2015). Pengaruh Pembelajaran Kewirausahaan Terhadap Minat Mahasiswa UPP Berwirausaha. Jurnal Ilmiah Cano Ekonomos, 3(1), $69 \quad-\quad 78 . \quad$ Dari $\underline{\text { https://e- }}$ journal.upp.ac.id/index.php/Cano/article/view/1262.

Amanda, J. (2018). Pengaruh Pembelajaran Kewirausahaan, Lingkungan Pergaulan, dan Latar Belakang Ekonomi Keluarga Terhadap Minat Berwirausaha Mahasiswa S1 Universitas Negeri Yogyakarta. Jurnal

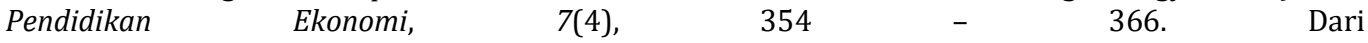
http://journal.student.uny.ac.id/ojs/index.php/ekonomi/article/view/10966.

Aradea, R. (2018). Analisis Motivasi Berwirausaha Mahasiswa Pada Program Studi Pendidikan Akuntansi FKIP Universitas PGRI Palembang. Jurnal Neraca, 2(2), 81 - 96. Dari https://jurnal.univpgripalembang.ac.id/index.php/neraca/article/view/2691.

Arikunto, Suharsimi. (2013). Prosedur Penelitian Suatu Pendekatan Praktik. Jakarta : PT Rineka Cipta.

Cristianingrum \& Rosalina, E. (2017). Pengaruh Pembelajaran Kewirausahaan Terhadap Minat Berwirausaha (Studi Kasus Pada Mahasiswa Manajemen, Akuntansi dan Sosiologi, Universitas Bangka Belitung). Integrated Journal of Business and Economics (IJBE), 1(1), 45 - 55 . Dari https://zenodo.org/record/571256\#.X8xbPU8xcwA.

Dewi, V.N., Casmudi., \& Deden. (2019). Pengaruh Pembelajaran Kewirausahaan dan Kreativitas Usaha Terhadap Minat Berwirausaha Siswa Kelas XI SMA Patra Dharma Balikpapan Tahun Ajaran 2018/2019. Jurnal Edueco Universitas Balikpapan, 2(2), 36 - 41. Dari https://jurnal.peko.unibabpn.ac.id/index.php/Edueco/article/view/43.

Doni, F.R. (2017). Perilaku Penggunaan Media Sosial Pada Kalangan Remaja. Indonesian Journal on Software Engineering, 3(2), 15 - 23. Dari https://ejournal.bsi.ac.id/ejurnal/index.php/ijse/article/view/2816.

Fahmi, R. (2012). Pengaruh Pembelajaran Kewirausahaan Terhadap Motivasi Berwirausaha. Jurnal Ekonomi dan Keuangan Islam, 1(2), $99 \quad-\quad 117 . \quad$ Dari https://jurnal.arraniry.ac.id/index.php/Share/article/view/720.

Fahmi, R \& Amanda,T. (2017). Pengaruh Pembelajaran Kewirausahaan Terhadap Minat Berwirausaha Mahasiswa. JEBI (Jurnal Ekonomi dan Bisnis Islam), 2(1), 33 - 42. Dari https://journal.febi.uinib.ac.id/index.php/jebi/article/view/65.

Herman, H. (2017). Pengaruh Motivasi Berwirausaha dan Kegiatan Penyuluhan Kewirausahaan yang Dilaksanakan Oleh Dinas Tenaga Kerja Kota Batam Terhadap Minat Berwirausaha di Kota Batam. Jurnal Ilmiah Manajemen, 5(2), 57 - 68. Dari http://ejournal.upbatam.ac.id/index.php/jim/article/view/242.

Indirianti, R., Sutrisno, D., \& Bambang, S. (2017). Pengaruh Motivasi dan Disiplin Belajar Terhadap Hasil Belajar Mata Pelajaran Prakarya dan Kewirausahaan. Jurnal Pendidikan Ekonomi: Jurnal Ilmiah Ilmu Pendidikan, Ilmu Ekonomi dan Ilmu Sosial, 11(2), 69 - $75 . \quad$ Dari https://jurnal.unej.ac.id/index.php/JPE/article/view/6449.

Indoworo, H.E. (2016). Menumbuhkan Jiwa Wirausaha Melalui Peran Sosial Media. Jurnal Informatika UPGRIS, 2(1), 45 - 55. Dari http://journal.upgris.ac.id/index.php/JIU/article/view/1067.

Indriyatni, L. (2013). Pengaruh Mata kuliah Kewirausahaan Dalam Menumbuhkan Minat Mahasiswa Untuk Berwirausaha (Studi Kasus Pada Mahasiswa STIE Pelita Nusantara Semarang). Fokus Ekonomi Jurnal Ilmiah Ekonomi, 8(1), 52 - 59. Dari https://ejournal.stiepena.ac.id/index.php/fe/article/view/118. 
Iswandari, A. (2013). Pengaruh Motivasi Intrinsik, Pengetahuan Kewirausahaan, dan Kepribadian Terhadap Minat Berwirausaha Pada Siswa SMKN 12 Surabaya. Jurnal Ekonomi Pendidikan dan Kewirausahaan, 1(2), 152 - 162. Dari https://journal.unesa.ac.id/index.php/jepk/article/view/705.

Kamal, A.H \& Thoyyibah, N. (2020). Analisis Faktor - Faktor yang Mempengaruhi Minat Berwirausaha Santri Pondok Pesantren. At - Taqaddum, 12(1), 75 - 90. Dari https://www.researchgate.net/publication/343440880_Analisis_FaktorFaktor Yang Mempengaruhi Minat Berwirausaha Santri Pondok Pesantren.

Listiawati, M., S I Cicilia, D., \& Susantiningrum. (2020). Pengaruh Pembelajaran Kewirausahaan dan Pemanfaatan Media Sosial Terhadap Minat Berwirausaha di Mahasiswa FKIP UNS. Jurnal Kewirausahaan dan Bisnis, 25(1), 27 - 36. Dari https://jurnal.uns.ac.id/kewirausahaan-danbisnis/article/view/43386.

Penyusun, T. (2017). Pedoman Penulisan Karya Ilmiah: Skripsi (Doctoral dissertation, Tesis, Disertasi, Artikel, Makalah, Tugas Akhir, Laporan Penelitian. Malang: Universitas Negeri Malang).

Prasetio, T. (2020). Analisis Pengaruh Penggunaan Media Sosial, Motivasi Intrinsik, dan Pengetahuan Kewirausahaan Terhadap Minat Berwirausaha Mahasiswa. Jurnal Sekretari \& Administrasi (Serasi), 18(1), 35-46. Dari https://journal.budiluhur.ac.id/index.php/serasi/article/view/1040.

Pratiwi, Y \& Wardana, I.M. (2016). Pengaruh Faktor Internal dan Eksternal Terhadap Minat Berwirausaha Mahasiswa Fakultas Ekonomi dan Bisnis Universitas Udayana. E - Jurnal Manajemen Unud, 5(8), 5215 - 5242. Dari https://ojs.unud.ac.id/index.php/Manajemen/article/view/22691.

Pratomo, R.P.K., Mulyadi, H., \& Utama, D.H. (2018). Pengaruh Pembelajaran Kewirausahaan Terhadap Kesiapan Berwirausaha Siswa Kelas XII Pastry Sekolah Menengah Kejuruan Negeri 9 Bandung. Journal of Business $\begin{array}{llllll}\text { Management } \quad \text { Education, } & 3(2), & 67 & - & 77 . & \text { Dari }\end{array}$ https://ejournal.upi.edu/index.php/[BME/article/view/14216.

Prilovia, H. \& Iskandar. (2018). Minat Wirausaha Mahasiswa Fakultas Ekonomi UNSW Agati Cirebon. Jurnal Edunomic, 6(2), 57 - 64. Dari http://jurnal.ugj.ac.id/index.php/Edunomic/article/view/1510/894.

Rahayu, E.S \& Laela, S. (2018). Pengaruh Minat Berwirausaha dan Penggunaan Sosial Media Terhadap Kewirausahaan Mahasiswa. Jurnal Pengembangan Wiraswasta, 20(03), 203 - 216. Dari http://ejurnal.stieipwija.ac.id/index.php/ipw/article/view/246.

Rahmiyanti, S \& Nuraisiah, R. (2019). Pengaruh Pembelajaran Kewirausahaan Terhadap Minat Berwirausaha (Studi Kasus Pada Mahasiswa Manajemen, Akuntansi dan Ilmu Komputer, Universitas Kota Serang). Jurnal Kajian Pendidikan dan Pengajaran, 5(2), 103 - $111 . \quad$ Dari https://im.ejournal.id/index.php/mendidik/article/view/74.

Rajagukguk, Z. (2016). Karakteristik Kewirausahaan Pengusaha Kecil dan Strategi Pengembangan Usahanya di Masa Depan : Studi Kasus Pengusaha Pakaian Jadi di Depok. Jurnal Kependudukan Indonesia, 11(1), 49 - 62. Dari https://ejurnal.kependudukan.lipi.go.id/index.php/jki/article/view/67.

Rosmiati., Junias, D.T.S., \& Munawar. (2015). Sikap, Motivasi, dan Minat Berwirausaha Mahasiswa. Jurnal Manajemen dan Kewirausahaan, 17(1), $21 \quad$ - $30 . \quad$ Dari http://jurnalmanajemen.petra.ac.id/index.php/man/article/view/19227.

Sahroh, A.F. (2018). Pengaruh Literasi Ekonomi dan Tingkat Penggunaan Media Sosial Terhadap Minat Berwirausaha Mahasiswa Fakultas Ekonomi di Universitas Negeri Surabaya.JUPE, 6(3), 208 - 215. Dari https://ejournal.unesa.ac.id/index.php/jupe/article/view/25242.

Sari, I.M., Harahap, P., \& Ridwan, R. (2018). Pengaruh Faktor Internal dan Faktor Eksternal Terhadap Minat Berwirausaha ( Studi Kasus Pada Mahasiswa FEBI IAIN Langsa). Al - Muamalat Jurnal Hukum Ekonomi $\begin{array}{lllll}\text { Syariah, } & 3(02), & 179 & 200 . & \text { Dari }\end{array}$ https://journal.iainlangsa.ac.id/index.php/muamalat/article/view/721.

Statistik, B. P. (2018). Keadaan Ketenagakerjaan Indonesia Februari 2018. Badan Pus. Stat, (42/05), 1-16.

Suharyono. (2017). Sikap dan Perilaku Kewirausahaan. Jurnal Ilmu dan Budaya, 40(56), 6551 - 6585. Dari http://journal.unas.ac.id/ilmu-budaya/article/view/422.

Sukirman. (2017). Jiwa Kewirausahaan dan Nilai Kewirausahaan Meningkatkan Kemandirian Usaha Melalui Perilaku Kewirausahaan. Jurnal Ekonomi dan Bisnis, 20(1), 113 - 132. Dari https://ejournal.uksw.edu/jeb/article/view/318.

Suyatno, A \& Muhtarom, M. (2018). Pengaruh Lingkungan Keluarga dan Pembelajaran Kewirausahaan Terhadap Intensi Techopreneurship Mahasiswa Manajemen Ilmu Komputer. Prosiding SENDI_U, 171 177. Dari https://www.unisbank.ac.id/ojs/index.php/sendi_u/article/view/5978. 
Jurnal Ekonomi, Bisnis dan Pendidikan, 1(9), 2021, 871-888

Syarifuddin, D., Iskandar, I., \& Hakim, L. (2017). Dampak Lingkungan Terhadap Minat Mahasiswa Pariwisata Berwirausaha ( Studi Kasus pada Mahasiswa STP ARS Internasional, Bandung). Jurnal Pariwisata, IV(1), 40 - 52. Dari https://ejournal.bsi.ac.id/ejurnal/index.php/ip/article/view/1831.

Wanto, S.F. (2014). Pengaruh Kemandirian dan Motivasi Berwirausaha Terhadap Minat Berwirausaha Siswa SMKN 1 Seyegan. E - Jurnal Pendidikan Vokasional Teknik Mesin, 2(3), 185 - 191. Dari http://journal.student.uny.ac.id/ojs/index.php/mesin/article/view/3379.

Wijayangka, C., Kartawinata, B.R., \& Novrianto, B. (2018). Pengaruh Motivasi Terhadap Minat Berwirausaha Mahasiswa Program Studi Administrasi Bisnis Universitas Telkom. Eco - Buss, 1(2), 73 - 79. Dari https://jurnal.kdi.or.id/index.php/eb/article/view/34.

Wulandari, R.P., Wagimin, Ign., \& Susilowati, T. (2013). Pengaruh Pembelajaran Kewirausahaan dan Lingkungan Keluarga Terhadap Minat Berwirausaha. Jurnal Pendidikan Administrasi Perkantoran Universitas Sebelas Maret, 4(1). Dari https://www.neliti.com/id/publications/118334/pengaruhpembelajaran-kewirausahaan-dan-lingkungan-keluarga-terhadap-minat-berwi\#cite.

Yulastri, A. (2019). Karakter Wirausaha. Bandung: Alfabeta. 